\title{
Inclusive Education Setting in Southwestern Nigeria: Myth or Reality?
}

\author{
Fareo Dorcas Oluremi
}

Counselling \& Human Development Centre, Adeyemi College of Education, Nigeria

Copyright (C) 2015 by authors, all rights reserved. Authors agree that this article remains permanently open access under the terms of the Creative Commons Attribution License 4.0 International License.

\begin{abstract}
Researches from developed and developing countries found that there were problems affecting the inclusive education in Nigeria. Hence, there is need to determine the challenges facing the schools where inclusive education is being implemented, and what could be done to improve the programme. The study showed that essential facilities and materials like hand railings, hearing aids, Braille, instructional materials, and lower toilets were not available, although the few that were available (typewriters, resource rooms, wheel chairs) were in poor condition. The difference between the attitude of special and regular teachers to students with special educational needs was significant with a t-test value of $1.91(\mathrm{P}<0.05)$. The influence of students with special educational needs exceptionality types in their self-perception was significant with a Chi-square analysis of $39.75(\mathrm{P}<0.05)$. However, the difference between the academic performance of male and female students with special educational needs was not significant with a t-test value of $1.19(\mathrm{P}>0.05)$. The study concluded that inclusive education was a reality in Nigeria because it became an educational policy since 1977 that all the states should have inclusive schools for students with special educational needs; and this has been in operation in Nigeria since then. Nevertheless, students with special educational needs were yet to be fully integrated into regular classroom setting. This was due to problems affecting inclusion; which could negatively affect their social and academic performance. The school curriculum should be modified to meet specific needs and purpose of educating students with special educational needs. Efforts should be made by government and other stakeholders of education to frequently expose teachers in mainstreamed setting to workshop and seminars on education of students with special educational needs.
\end{abstract}

Keywords Inclusive Education, Integrated Schools, Mainstreamed Schools, Students with Disabilities, Students with Special Educational Needs, Inclusion

\section{Introduction}

Children are gifts from God and they are unique, different from one another physically, mentally, emotionally and socially. Most children can learn in regular classes without the need for special service teachers. There is, however, a group of individuals in our communities and schools, whose conditions of life are at the extreme that they find it difficult to benefit from the general regular educational programme, and therefore require special education programmes to cope with circumstances of life. In literature, such individuals are referred to as children with special educational needs. According to Vendan et al [24], children with special educational needs are exceptional children or differently challenged, who might be physically, socially or intellectually different, either below or above average, which require individually planned and systematically monitored arrangements of physical settings.

Olukotun [19] stated that the education of children with special educational needs started with segregation, however; segregation system has its disadvantages, because it fails to recognize the fact that children with special educational needs are part of the community and the society at large. This implies that segregation places more restriction and social handicap on the social needs of youths and adults in their later years. The goal of education is to introduce measures that would benefit the child maximally in the learning environment. The nature of students with special educational needs precludes access to learning conditions; it becomes imperative to design alternative strategies for assisting students with special educational needs. One such strategy is inclusion which is an educational arrangement that brings both students with special educational needs and regular students together under one learning environment. By this school programme, students with special educational needs lived with their parents or guardians and attend school in the neighbourhood. According to Bryant et al [8]; Lipsky et al. \& Salend [21], they posited that inclusive education can be interpreted as the philosophy and practice for educating students with disabilities in general education settings, inclusive refers to the "full-time placement of children with mild and moderate disabilities in regular classrooms'. 
According to Garuba [11], inclusion is a step further in mainstreaming, as it presents a means "by which a school attempts to respond to all pupils as individuals, by reconsidering and structuring its curricular organization and provision, and allocating resources to enhance equality of opportunity. Smith [22] defined inclusion as the commitment to educate each child to the maximum extent appropriate; in the school and classroom he/she would otherwise attend. It involves bringing the ancillary services to the child, and requires only that the child will benefit from being in the class (rather than having to keep up with the other students). This is salient aspect of inclusion, and requires a commitment to move essential resources to the child with a disability rather than placing the child in an isolated setting where services are located. Ajuwon [2] opined that for the child with a disability to benefit optimally from inclusion, it is imperative for general education teachers to be able to teach a wider array of children, including those with varying disabilities and to collaborate and plan effectively with special education.

According to Adedokun et al [1], inclusion may be partial or full. Full inclusion is the integration of all students, even those that require substantial educational and behavioural supports and services to be successful in regular classes and the elimination of segregated special classes. In full inclusion, special education is considered a service not a place and those services are integrated into daily routines and classroom structure, environment, curriculum and strategies and brought to the student instead of removing the student to meet his/her individual needs. Partial inclusion on the other hand represents a situation where students with special needs are educated in regular classes but when there is need for any special service like speech therapy, these students with special needs are pulled out of the regular classroom for these special services. It is therefore imminent that what is in practice now is more of integrated/mainstreaming type of education and not full inclusive education. Strully et al [23] asserted that inclusive education is important in the development of Nigerian communities because bringing students with and without special needs together show the younger generation that a diverse group of people make up a community and that no one type of student is better than another. Inclusive education will thus remove barrier to friendship among students with and without special needs, imbibing in them the spirit of cooperation and team work which is the essential ingredient germane to community development.

Nigeria for example, adopts the policy of inclusion in her National Policy on Education by Federal Republic of Nigeria [14]. The policy stipulates the integration of special needs students into regular classrooms, and free education for exceptional students at all levels. The commitment is made to equalize educational opportunities for all children, irrespective of their physical, sensory, mental, psychological or emotional disabilities. Undoubtedly, these are lofty goals intended to improve the quality of special education services, but much more is needed to translate the goals into concrete action. However, inclusive education has not been without its attendant problems. Studies however assert that the inclusive schools lack adequate technology equipment and incentives needed to provide special needs education in Nigeria. Fabunmi [9] found that educational facilities were differently allocated across secondary schools in Edo State. Nwazuoke [16] and Mittler, [13] observed that many teachers who were in inclusive schools appeared to know little or nothing with children with special needs. Bevan-Brown [7] reported that she had "a whole truck load" of stories about poor attitude and expectations of teachers to students with disabilities. She found that many teachers demonstrated negative attitude to students with special educational needs in secondary schools. Sadly, this situation negatively affected the education and performance of children with special needs. This was also found to affect these learners' self-esteem. Basically, therefore the researcher intended to find out how inclusive education programme in Nigeria is being managed.

\subsection{Objectives of the Study}

The Study was carried out to achieve the following objectives

- To determine the availability and convenience of the facilities that are provided to students with special needs in mainstreamed public secondary schools;

- To examine the qualifications of teachers teaching in mainstreamed public secondary schools;

- To determine the influence of types of exceptionality on self-perception of students with special educational needs.

\subsubsection{Research Question}

Research Question: What are the facilities that are available to students with special educational needs in mainstreamed public secondary schools in Southwestern Nigeria?

\subsubsection{Research Hypotheses}

1. Research Hypothesis 1: There is no significant difference in the attitude of special and regular teachers to students with special educational needs.

2. Research Hypothesis 2: Types of exceptionality do not significantly influence the self-perception of students with special educational needs.

\section{Methodology}

\subsection{Research Design}

The study employed the descriptive survey design to gather information from a representative sample of the population under study. The design of this study involved the 
administration of the test instruments on subjects and obtaining their responses on attitude of teachers and regular students to students with special needs, the facilities available and the convenience of the building layout in mainstreamed public schools; self-perception of students with special needs; and academic performance of regular students and students with special needs

\subsection{Population and Sample}

The population for this study comprised 1,371 students with special needs, and 2,701 teachers in the 35 public secondary schools where mainstreaming of students with special needs is being implemented in Southwestern Nigeria. Five out of the six (Ogun, Oyo, Lagos, Ondo and Ekiti) States in Southwestern Nigeria were selected for the study with the exception of Osun State, which was used for test of reliability. Purposive sampling technique was used to select 10 out of the 35 mainstreamed public secondary schools, based on the number of students with special needs in the schools. From the selected schools, the 910 students with special needs, and 200 teachers were selected for the study.

\subsection{Validity and Reliability of Research Instruments}

\subsubsection{Validity of Research Instrument}

The validity of the three instruments used in this study was thus described. The content and face validity of the three instruments Teachers Attitude to Students with Special Needs "TASSN;" Self Perception of Students with Special Needs "SPSSN"; and School Observation Checklist "SOC" were carried out by two experts in Test and Measurement, an expert in Psychology of Education; and an expert in Guidance and Counselling. Appropriate suggestions were made to improve the quality of the questionnaire by deleting the inappropriate question items, and by modifying some.

\subsubsection{Reliability}

The researcher used test-retest reliability method to determine the reliability of the instruments. The retest was carried out three weeks after the first test. On each of the three instruments (Self Perception of Students Special Needs "SPSSN", and Teachers Attitude to Students with Special Needs "TASSN" questionnaires were administered on 30 students. The test-retest on "TASSN" yielded reliability co-efficient of 0.82 , while. The test-retest on "SPSSN" yielded reliability co-efficient of 0.84 . Therefore, the questionnaires were deemed fit and reliable for the study.

\subsection{Collection and Analysis of Data}

Data were collected by the researcher for two weeks in five states in Nigeria; and the respondents were persuaded to fill the questionnaires on the spot. Special teachers assisted the researcher in interpreting the questionnaire to hearing impaired students during the process of administration. The visually impaired students and teachers' questionnaire were administered to them on one to one basis. Two hundred copies of the questionnaires were administered to the teachers, but, 190copies were retrieved. Seven hundred and ninety two copies were collected from 810 copies of the questionnaires administered to students with special needs. Ten copies of the questionnaires were not correctly filled, so, the analyses of data were based on 782 copies.

Table 1. Selected Mainstreamed Public Secondary Schools in Southwestern Nigeria

\begin{tabular}{|c|c|c|c|c|}
\hline $\mathrm{S} / \mathrm{N}$ & States & Schools & Number & $\begin{array}{c}\text { Categories of students with } \\
\text { special needs }\end{array}$ \\
\hline i. & Ekiti & $\begin{array}{l}\text { Amoye Grammar School, Ikere-Ekiti. } \\
\text { Ekiti -Parapo College, Ido-Ekiti. }\end{array}$ & $\begin{array}{l}78 \\
53\end{array}$ & $\begin{array}{l}\text { Hearing impaired students } \\
\text { Physically impaired students }\end{array}$ \\
\hline ii. & Lagos & State Grammar School, Eric -Moore & 103 & Hearing impaired students \\
\hline iii. & Ogun & $\begin{array}{c}\text { St. Peter's College, Abeokuta } \\
\text { Rev. Kuti Memorial High School, Abeokuta } \\
\text { Yewa College, Ilaro }\end{array}$ & $\begin{array}{c}171 \\
31 \\
35 \\
\end{array}$ & $\begin{array}{l}\text { Hearing impaired students } \\
\text { Physically impaired students } \\
\text { Visually impaired students } \\
\end{array}$ \\
\hline Iv & Ondo & Akure High School, Akure & 125 & Hearing impaired students \\
\hline v. & Оуо & $\begin{array}{c}\text { Ijokodo High School, Ibadan } \\
\text { Methodist High School, Ibadan } \\
\text { Adeniran Memorial Grammar School, Ogbomoso } \\
\end{array}$ & $\begin{array}{c}69 \\
213 \\
32 \\
\end{array}$ & $\begin{array}{l}\text { Physically impaired student } \\
\text { Hearing impaired students } \\
\text { Visually impaired students } \\
\end{array}$ \\
\hline & Total & 10 & 910 & 3 Categories \\
\hline
\end{tabular}


Table 2. Facilities Available for Students with Special Educational Needs in Mainstreamed Public Secondary Schools in the Five States

\begin{tabular}{|c|c|c|c|c|c|c|c|c|c|c|c|c|}
\hline \multicolumn{3}{|r|}{$\mathrm{I}$} & \multicolumn{2}{|r|}{ II } & \multicolumn{2}{|r|}{ III } & \multicolumn{2}{|c|}{ IV } & \multicolumn{2}{|l|}{$\mathrm{V}$} & \multicolumn{2}{|c|}{ All States } \\
\hline Facilities & & $50 \quad \%$ & & $=50 \quad \%$ & & $0 \quad \%$ & & $50 \%$ & & $50 \quad \%$ & & $50 \quad \%$ \\
\hline Hearing aids & 0 & $0.0 \%$ & 0 & $0.0 \%$ & 0 & $0.0 \%$ & 0 & $0.0 \%$ & 0 & $0.0 \%$ & 0 & $0.0 \%$ \\
\hline School bus & 35 & $70 \%$ & 0 & $0.0 \%$ & 40 & $80 \%$ & 45 & $90 \%$ & 0 & $0.0 \%$ & 120 & $48 \%$ \\
\hline Resource room & 0 & $0.0 \%$ & 0 & $0.0 \%$ & 30 & $60 \%$ & 20 & $40 \%$ & 0 & $0.0 \%$ & 60 & $24 \%$ \\
\hline Play ground & 50 & $100 \%$ & 20 & $40 \%$ & 45 & $90 \%$ & 50 & $100 \%$ & 40 & $80 \%$ & 205 & $82 \%$ \\
\hline $\begin{array}{c}\text { Instructional } \\
\text { materials }\end{array}$ & 0 & $0.0 \%$ & 0 & $0.0 \%$ & 20 & $40 \%$ & 20 & $40 \%$ & 0 & $0.0 \%$ & 40 & $16 \%$ \\
\hline Wheel chair & 30 & $60 \%$ & 0 & $0.0 \%$ & 20 & $40 \%$ & 0 & $0.0 \%$ & 40 & $80 \%$ & 90 & $36 \%$ \\
\hline Lower toilets & 0 & $0.0 \%$ & 0 & $0.0 \%$ & 0 & $0.0 \%$ & 0 & $0.0 \%$ & 0 & $0.0 \%$ & 0 & $0.0 \%$ \\
\hline Walking stick & 30 & $60 \%$ & 0 & $0.0 \%$ & 0 & $0.0 \%$ & 0 & $0.0 \%$ & 0 & $0.0 \%$ & 30 & $12 \%$ \\
\hline Braille & 0 & $0.0 \%$ & 0 & $0.0 \%$ & 0 & $0.0 \%$ & 0 & $0.0 \%$ & 0 & $0.0 \%$ & 0 & $0.0 \%$ \\
\hline Type-writer & 0 & $0.0 \%$ & 0 & $0.0 \%$ & 30 & $60 \%$ & 0 & $0.0 \%$ & 25 & $50 \%$ & 85 & $34 \%$ \\
\hline Special teachers & 20 & $40 \%$ & 15 & $30 \%$ & 40 & $80 \%$ & 30 & $60 \%$ & 30 & $60 \%$ & 135 & $54 \%$ \\
\hline Counselling office & 0 & $0.0 \%$ & 0 & $0.0 \%$ & 20 & $40 \%$ & 20 & $40 \%$ & 15 & $30 \%$ & 55 & $22 \%$ \\
\hline Building layout & 25 & $50 \%$ & 30 & $60 \%$ & 40 & $80 \%$ & 50 & $100 \%$ & 35 & $70 \%$ & 180 & $72 \%$ \\
\hline Clear floor space & 35 & $70 \%$ & 30 & $60 \%$ & 42 & $84 \%$ & 48 & $96 \%$ & 38 & $76 \%$ & 193 & $77.2 \%$ \\
\hline $\begin{array}{l}\text { Wider doors and } \\
\text { corridors }\end{array}$ & 32 & $64 \%$ & 35 & $70 \%$ & 45 & $90 \%$ & 47 & $94 \%$ & 34 & $68 \%$ & 196 & $78.4 \%$ \\
\hline
\end{tabular}

Key:- $\quad \mathrm{N}=$ Number of Scores $\quad$ State I = Ekiti State

State II = Lagos State $\quad$ State III = Ogun State

State IV = Ondo State $\quad$ State V = Oyo State

\section{Results}

The results of the analyses are presented as follows:

Research Question: What are the facilities that are available to students with special educational needs in mainstreamed public secondary schools in Southwestern Nigeria? To answer the question, some available facilities were extracted from the data collected on "School Observation Checklist". The data are subjected to percentage analysis. The results are presented in Table 2

From Table 2, the data indicated the conditions of the facilities available in each of the schools. Playground scored $50(100 \%)$, school bus scored $35(70 \%)$, wheel chair scored $30(60 \%)$, special teachers scored $20(40 \%)$, building layout scored $25(50 \%)$, clear floor space scored $35(70 \%)$ and wider doors and corridors scored 32 (64\%). In State I, the materials and facilities that were not available include a counselling office, resource rooms, lower toilets, hearing aids, instructional materials, Braille typewriters and special textbooks.

In State II, the available facilities were playground, which scored $20(40 \%)$, special teachers, $15(30 \%)$, building layout, $30(60 \%)$, clear floor space, $30(60 \%)$ and wider doors 35 $(70 \%)$. The materials and facilities not available in this state were a counselling office, resource room, lower toilets, hearing aids, instructional materials and special textbooks.

In State III, the available materials and facilities were school bus, which scored 40 (80\%), instructional materials,
$20(40 \%)$, wheel chair, $20(40 \%)$, typewriter, $30(60 \%)$, special teachers, $40(80 \%)$, resource room, $30(60 \%)$, playground, $45(90 \%)$, clear floor space, $42(84 \%)$, while wider doors and corridors scored $45(90 \%)$. The items and facilities not available in State III were hearing aids, walking stick, lower toilets, Braille and special textbooks.

In State IV, the available materials and facilities were school bus, which scored $45(90 \%)$, resource room, 20 (40\%), playground, $50(100 \%)$, instructional materials, $20(40 \%)$, special teachers, $30(60 \%)$, a counselling office, $20(40 \%)$, building layout, $50(100 \%)$, clear floor space, $48(96 \%)$ and wider doors and corridors, 47 (94\%); but hearing aids, special textbooks and lower toilets were not available.

In State V, the available materials and facilities were wheel chair, which scored $40(80 \%)$, typewriter, $25(50 \%)$, special teachers, $30(60 \%)$, playground, $40(80 \%)$, a counseling office, $15(30 \%)$, building layout, 35 (70\%), clear floor space, 38 (76\%) and wider doors and corridors, 34 (68\%). Also in State V, hearing aids, walking stick, Braille and special textbooks, instructional materials, school bus, resource room and lower toilets were not available. in the five States.

Research Hypothesis 1: There is no significant difference in the attitude of special and regular teachers to students with special educational needs. To Test this hypothesis, data collected on special and regular teachers to students with special educational needs were subjected to t-test analysis. 
Table 3. Difference between the Attitude of Special and Regular Teachers to Students with Special Educational Needs.

\begin{tabular}{|c|c|c|c|c|c|c|}
\hline Categories of teachers & $\mathrm{N}$ & $\bar{x}$ & $\mathrm{SD}$ & $\mathrm{df}$ & $\mathrm{t}$ & $\mathrm{P}$ \\
\hline Special teachers attitude & 46 & 60.09 & 11.17 & \multirow{2}{*}{188} & \multirow{2}{*}{1.91} & $<.05$ \\
\hline Regular teachers attitude & 144 & 56.51 & 10.99 & & & \\
\hline
\end{tabular}

* Significant $(\mathrm{P}<0.05)$

Table 4. Influence of Types of Exceptionality in Self Perception of Students with Special Educational Needs

\begin{tabular}{|c|c|c|c|c|c|}
\hline Types of Exceptionality & Positive Self Perception & Negative Self Perception & $x^{2}$ & $\mathrm{df}$ & $\mathrm{P}$ \\
\hline Count & 351 & 322 & \multirow{8}{*}{39.75} & \multirow{8}{*}{2} & \multirow{8}{*}{$<.05$} \\
\hline Hearing impaired & $52.2 \%$ & $47.8 \%$ & & & \\
\hline Count & 41 & 8 & & & \\
\hline Physical impaired & $83.7 \%$ & $16.3 \%$ & & & \\
\hline Count & 51 & 9 & & & \\
\hline Visually impaired & $85.0 \%$ & $15.0 \%$ & & & \\
\hline Count & 443 & 339 & & & \\
\hline Total & $56.6 \%$ & $43.4 \%$ & & & \\
\hline
\end{tabular}

*Significant $(\mathrm{P}<0.05)$

From Table 3, two hundred copies of the questionnaires were administered to special teachers and regular teachers. One hundred and ninety copies were collected. The mean of special teachers' attitude to students with special educational needs was 60.09 , while the mean of regular teachers' attitude to students with special educational needs was 56.51 . The difference between the attitude of special and regular teachers to students with special educational needs was found to be significant with a t-test value of $1.91(\mathrm{P}<0.05)$.

Research Hypothesis 2: Types of exceptionality do not significantly influence the self-perception of students with special educational needs. To test this hypothesis, data collected on types of exceptionality and self-perceptions of students with special educational needs were subjected to chi-square analysis. The results are presented in Table 4

From Table 4 , three hundred and fifty one $(52.2 \%)$ hearing impaired students were with positive self-perception, while three hundred and twenty two (47.8\%) hearing impaired students were of negative self-perception. Forty one (83.7\%) physically impaired students were of positive self-perception, while eight $(16.3 \%)$ physically impaired students were of negative self-perception. Fifty one $(85.0 \%)$ visually impaired students were of positive self-perception, while nine $(15.0 \%)$ visually impaired students were of negative self-perception. Four hundred and forty three (56.6\%) students with special educational needs were of positive self-perception, while three hundred and thirty nine (43.4\%) students with special educational needs were of negative self-perception. Attempt was also made to determine the influence of students with special educational needs exceptionality types in their self-perception. Chi-square analysis was used. The result of the chi-square yielded 39.75, which was significant at 0.05 .

\section{Discussion}

The findings of the research question on available facilities in mainstreamed public secondary schools in Southwestern Nigeria, showed that there were unavailability of essential facilities and materials like hand railings, hearing aids, instructional materials, Braille and lower toilets, while the few materials and facilities (type writer, resource rooms, textbooks) available were in poor condition. This finding showed that lack of adequate facilities and materials were obstacles to effective learning. This finding supported the findings of Ohuche [17], and Ale [4] which showed that poor facilities, equipment and instructional materials were adduced for poor academic performance of students. The finding also corroborated the evidence of Anumonye, [5], Fabunmi [9]; and Nwazuoke [16], that mainstreaming of students with special educational needs into public secondary schools in Nigeria was faced with the problems of lack of relevant facilities and materials.

Another major finding showed that there was a significant difference between the attitude of special teachers and regular teachers to students with special to needs. The difference in the attitude of the two categories of teachers might be due to the training and exposure to special education courses, which enabled the special teachers to develop more positive attitude to students with special educational needs. This study was in line with Okeke ]18]; Fakolade et al [10] who observed those special teachers' exposures to special education courses enable them in identification and management of students with special educational needs. However, Safer et al [20] findings showed that the training programme did not influence the attitudes of teachers toward students with special educational needs.

Another major finding of this study showed that types of exceptionality had a significance influence on the self-perception of students with special educational needs. The positive self-perception of visually impaired students was the highest $(85.0 \%)$, while their negative self-perception was $15 \%$. The physically impaired students were the second 
on the list with $83.7 \%$ positive self-perception, while their negative self-perception was $16.3 \%$. Hearing impaired students had the least positive self-perception of $52.2 \%$ while their negative self-perception was $47.8 \%$. This finding showed that students with special educational needs had positive self-perception of themselves. The positive self-perception would make students with special educational needs to socially accept themselves that they were able to do effectively what other peers could do successfully. They had the right to live normal lives like other human being, even though their conditions bring about some limitations and difficulties. This finding was contrary to Johnson et al [11]. Who remarked that working with students with special educational needs demands that one should know that these individuals are often susceptible to low self-confidence, loss of self-esteem, high frustration level, anxiety, depression and despair.

\section{Conclusions}

The study concluded that inclusive education was a reality in Nigeria because it became an educational policy that all the states should have inclusive schools for students with special educational needs, and this has been in operation in all the 36 states in Nigeria. Nevertheless, students with special educational needs were yet to be fully integrated into regular classroom setting due to problems affecting inclusion..

\section{Recommendations}

Based on the findings of this study, the following recommendations are made for the government.

- The counsellors, the psychologists, the teachers, and other stakeholders. It is obvious that education is capital intensive, but educating the students with special educational needs is more capital intensive. The government should fund education, while mainstreamed schools should be "specially funded". Adequate funding would help to overcome the problem of provision and maintenance of special equipment and materials for the use of students with special educational needs.

- Counselling services for students with special educational needs is a necessary service that should be rendered by counsellors, psychologists and special teachers working with students with special educational needs in mainstreamed public school system. In the light of the fore going considerations, it is recommended to all school system to initiate seminars, workshops and conferences for parents of students with special educational needs; so that awareness could be brought about on needs of families.

- Most mainstreamed schools lack resource room services. This is a room specially equipped with modern teaching equipment and materials that one or more specialist teachers can use to offer assistance to students with special educational needs who require help in the respective subjects. A resource room should be established and equipped with modern teaching equipment. A specialist teacher should be made available to assist the classroom teacher in protecting the interest of the students with special educational needs in mainstreamed school.

- Efforts should be made by government and other stakeholders of education to frequently expose teachers in mainstreamed setting to workshop and seminars on education of students with special educational needs.

- Government should provide incentives, promotions, and regular payments of salaries to teachers in mainstreamed public secondary schools in order to enhance quality teaching, and positive attitude to implementation of mainstreaming of students with special educational needs in public school system.

- The school curriculum should be modified to meet specific needs and purpose of educating students with special educational needs. The regular school curriculum cannot be followed in working with students with special educational needs. There must be a special curriculum, specifically designed by educators to meet the need of these students with special educational needs. It is then and only then that we can meaningfully measure their capabilities and achievements.

- Teachers should put to use full ethics of their profession when teaching in inclusive schools. They should display the knowledge of psychology and use appropriate methods that would help all the students learn.

- Teachers should learn to be kind, patient but firm with all groups of learners. They should discipline them when there is need for it and they should view all learners as being equal in class and so none should be pitied.

- Counselling rooms/offices should be created by the school authorities, where effective counselling services should be handled by well trained and qualified counsellors.

- Nigerians must do away with the cultural beliefs that do not allow them to readily accept these children, their acceptance would foster good social integration of able-bodied and children with special needs.

- Large classes should be discouraged, as this would not allow for individual attention by the teachers.

\section{REFERENCES}

[1] Adedokun, M.O. \& Olaleye, F.O. (2014). Inclusive education and the development of Nigerian communities. International Journal of Academic Research in Progressive Education and Development, 3 (1), 28-40.

[2] Ajuwon, P.M. (2008). Inclusive education for students with 
disabilities in Nigeria: Benefits challenges and policy implications. International Journal of Special Education. 23(3), 11-16.

[3] Akinpelu, O.F. (1998). A study of the academic achievement and self-concept of male and female hearing-impaired students in Nigeria. The Nigerian Journal of Guidance \& Counselling, 6(1\&2), 1-10.

[4] Ale, S. O. (1989) 'School Mathematics in the 1990's:some major problems for students' quality output in Nigerian secondary schools.' The Journal of International Social Research, 1, 5 .

[5] Anumonye, F. O. (1991) 'Problems of mainstreaming handicapped children in Nigeria.' In E. D. Ozoji, J. U.Umolu \& S. O. Olaniyan (eds), Contemporary Issuesin Mainstreaming Exceptional Children in Nigeria6-3-3-4 System of Education, pp.65-69. Jos, Nigeria: National Council for Exceptional Children.

[6] Babatola, O. F. (1987) A study of English Language Achievement of Hearing and Hearing Impaired Secondary School Students in Oyo State. Unpublished B.Ed Thesis, University of Ibadan, Ibadan.

[7] Bevan-Brown, J. (2000). Running the gauntlet: A gifted moan learner's journey through secondary school. Gifted Pedagogy.

[8] Bryant, D.P., Smith, D.D., \& Bryant, B.R. (2008). Teaching Students with special educational needs in Inclusive classrooms. Boston. M.A. Pearson Education, Inc.

[9] Fabunmi, M. (1997). Deferential allocation of educational resources and secondary school academic performance in Edo-State, Nigeria, (1989-94) Unpublished Ph.D. Thesis, University of Ibadan.

[10] Fakolade, O.A; Adeniyi, S.O; \& Tella, A.(2009). Attitude of teachers towards the inclusion of special needs children in general education classroom: The case of teachers in some selected schools in Nigeria. International Electronic Journal of Electronic Education,.Vol.1, Issue 3, 164-169.

[11] Federal Republic of Nigeria (1997). National Policy of Education, NERC PRESS.

[12] Federal Republic of Nigeria (2004). National Policy of Education. Section 7: Special Needs Education. Abuja, Nigeria.

[13] Garuba, A. (2003). Inclusive education in the $21^{\text {st }}$ century: Challenges and opportunities for Nigeria. Asia Pacific
Disability Rehabilitation Journal.. 14(2).

Lipsky, D.K \& Gartner, A. (1997). Inclusion and school reform. Transforming America's Classroom. Baltimore, MD: Brookes Publishing CO.

[14] Johnson, S.W., \& Morasky, R.L. (1980). Learning disabilities. Boston: Allyn and Bacon. Inc. Lipsky, D.K \& Gartner, A. (1997). Inclusion and school reform. Transforming America's Classroom. Baltimore, MD: Brookes Publishing CO.

[15] Mittler, P. (2000). Working towards inclusive education. Social contexts. London. David Fulton Publishers, pp.1-14.

[16] Nwazuoke, I.A. (2000). Professional preparation of teachers of exceptional children for inclusive contexts. The Exceptional Children, 4, 1\&2, 14-16.

[17] Ohuche, R. O. (1978) 'Recent attempts at Mathematics curriculum renewal in English speaking West Africa.' Abacus, 12 (1), 1-6.

[18] .Okeke, B.A. (2000). Assessment of the adequacy of element of special education in teacher education. The Exceptional Child, 4, 1\&2, 20-23

[19] Olukotun, J. O. (2004). Inclusive education for children with special needs: A Component of the Universal Basic Education (UBE) programme. Ibadan Journal of Special Education, 1, .39-43.

[20] Safer, N.D., \& Agard, J.A. (1975). The effects of in-service training for regular class teachers within a mainstreaming model. Discussion draft. Project PRIME U.S.O.E. Intramural Research Programme, 1-6.

[21] Salend, S.J. (2001).Creating Inclusive Classrooms: Effective and reflective practices for all students. Fifth Edition; New Jersey: Pearson Education, Inc.

[22] Smith, D.D. (2007). Introduction to special education: Making a difference. $6^{\text {th }}$ edition. Boston, M.A. Pearson.

[23] Strully, J. \& Strully, C. (1996). Friendship as an educational goal: What we have learned and where we are headed. In Stainback, W. and Stainback, S. (Eds.). Inclusion: A guide for educators. Baltimore: Paul H. Brookes Publishing Co.

[24] Vendan, C.\& Peter, K. (2004) Assessment practice for early childhood intervention programmes for special needs persons. The Exceptional Children, Journal of NCEC Vol. 7, No.1\&2, 191-200. 